\title{
The Saudi resident and Tillsonburg
}

\author{
Cite as: CMAJ 2019 March 11;191:E287-8. doi: 10.1503/cmaj.181138
}

${ }^{66} \mathrm{~T}$

illsonburg ... my back still aches when I hear that word." The voice of the late Stompin' Tom Connors fills my living room on the east coast of Saudi Arabia against the protest of my wife. I am not sure if her objection is to the artist or to the choice of song. She would probably have been fine with Diana Krall or Michael Bublé. But the song and the town hold a special spot in my heart. Tillsonburg District Memorial Hospital was the first place I practised as a doctor. Fresh from my board examinations on a lovely summer morning, I saw my name for the first time as the attending physician on a patient's chart. It felt like being the author of a best-selling novel. In Tillsonburg, Ontario, I worked really hard.

Stompin' Tom was a soothing voice as I sat in my armchair contemplating the recent political dust up between the country where I was born and raised, and the country where I acquired my skills to be the physician I had always dreamed of becoming.

Physicians in both countries had nothing to do with what evolved in the summer of 2018. It began with a tweet from Global Affairs Canada, urging the Saudis to release those who its diplomatic staff considered to be peaceful human rights activists. The Kingdom saw these individuals as convicted criminals or suspected them of having activities against national security. The diplomatic fallout resulted in the suspension of the scholarships for thousands of Saudi students in Canada. That included 1053 residents who were told to leave Canada by Aug. 31, 2018. Canadian teaching hospitals were unsure how they would handle this loss. A reprieve came before that deadline: residents were told they could continue working in Canada until they could find another position elsewhere.

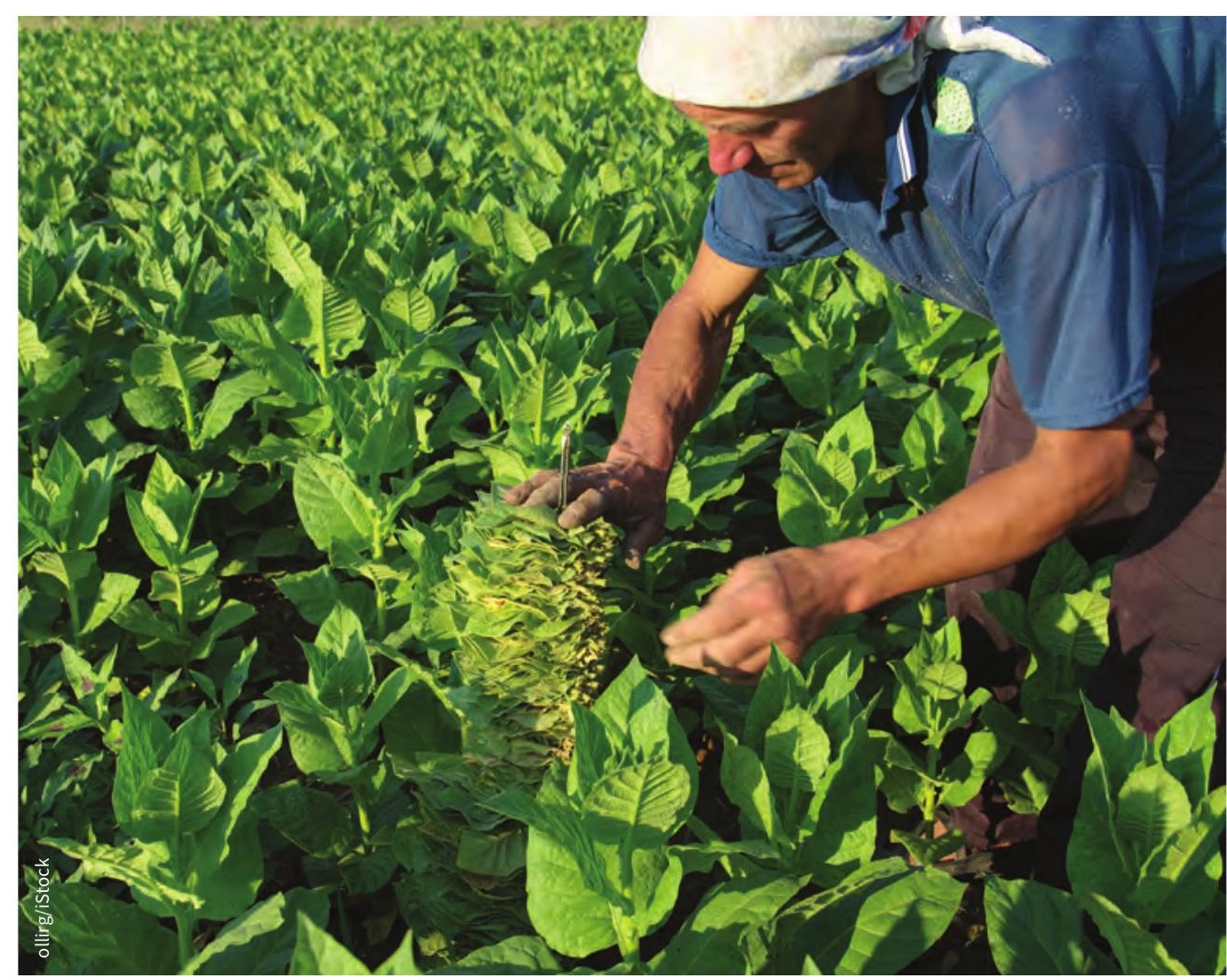

By the summer of 2018, several years had passed since I had completed my training in Canada and returned to Saudi Arabia. My Royal College certificate hung proudly on my wall, indicating in both English and French that I deserve to be a consultant in my specialty. I cannot help but think of the pain, sorrow and uncertainty that my colleagues now face given the potential threat of having their training cut short for no fault of their own.

My memory takes me back to my first trip to Canada when I applied for an internal medicine residency and was invited for interviews. First stop, Halifax. On the short walk from the historic Lord Nelson Hotel to Dalhousie University, my heart was beating fast and my hands were sweating, even in the crisp autumn air. I was worried about my upcoming interviews, but I was also trying to find someone to help me knot my tie. Where I come from, we do not wear suits and ties, not even to a funeral. A very kind tailor in his 70 s offered to help me for free and, after completing what seemed to me a more complicated task than the Licentiate of the Medical Council of Canada examinations, he wished me the best of luck in my interviews. Encouraged by his big-heartedness, I ended up wandering the downtown.

On my next stop, in Hamilton, Ontario, I wandered again and approached strangers, asking them about good restaurants in the area, shortly after midnight. The next morning, I shared my experience with the program director who interviewed me. Understandably, she declined my application; she probably accepted someone who had better judgment. 
"It is like a factory," my mentor in Saud Arabia explained to me before I started my residency in Halifax. He had just returned to the Kingdom after finishing his training in Toronto. He was spot on. If you work hard, you will be rewarded irrespective of your nationality, ethnicity or religion. The grinding nature of residency training engulfed us all.

There were a few embarrassing incidents, including spending my first three months suspecting tuberculosis in any patient who walked through the emergency door with fever. The pendulum swung at the end of my training. I became more interested in health problems related to my Canadian patients and less knowledgeable about diseases endemic in the Middle East. On my board examination, I failed to answer a simple question about a patient from my country who came in with suspected malaria infection. My Canadian counterparts answered the same question in a heartbeat.

What I valued the most about my training in Canadian universities is that it enshrined in my mind the principles of diversity, equality and fairness. I had a genuine belief that in this place, "... my four little children will not be judged by the color of their skin, but by the content of their character."2

The camaraderie with my Canadian friends carried on after I completed my training and took my first job as a staff gastroenterologist in Alberta. A few months into it, we welcomed our third child. While my wife was in labour, I struck up a conversation with her anes- thesiologist. We shared our concerns about the new pay schedule being introduced by the provincial government and feared that it might lead doctors with highly needed skills to leave the province. "You guys were more concerned about your paycheques than the pain I was going through!," my wife keeps reminding me as she recalls the events of that cold January day. She is right, and it was my fault, not his.

After I returned home to Saudi Arabia and established my practice, I kept returning to Canada for locums. I felt the distance was short. It felt even shorter one afternoon in a small rural town in the Canadian north. I needed a ride downtown and a senior surgeon in the hospital where I was working offered to take me there. After exchanging pleasantries, he asked me where I was from. To my surprise, the follow-up question was "Are you a Shia or Sunni?" He was referring to the two major sects in the Muslim world in general and in the eastern part of Saudi Arabia in particular. Clearly, this was not the kind of question you would expect in a sleepy town of 25000 half a world away from the sectarian tensions in the Middle East. It would be like sitting in a tent in the desert of the Arabian Peninsula and overhearing people talking about last night's game between the Montréal Canadiens and Toronto Maple Leafs. It turned out that my acquaintance had spent time in the region and knew the issues well.

As I reflect on the current situation, I sense both knowns and unknowns. I am certain that the research project I recently completed with a friend from Ontario will go ahead as planned. It was presented at a scientific conference in Philadelphia in the fall of $2018 .^{3}$

My four little children, two Canadians and two Saudis, will carry on living together, playing together and worshiping together. That being said, I am not sure if my children will be able to pursue a residency in Canada should one of them decide to become a doctor. I am hopeful that the situation will change, and hardworking Saudi residents will be allowed back into Canadian teaching hospitals.

Sitting on my armchair staring at my Royal College certificate, I notice the year of graduation. As the years pass by and I get older, my back sometimes bothers me. And yes, it "still aches when I hear that word" ... Tillsonburg. ${ }^{1}$

\section{Turki AlAmeel MBBS}

King Fahad Specialist Hospital - Dammam, Damman, Saudi Arabia

\section{References}

1. Stompin' Tom Connors. Tillsonburg [song]. Available: www.metrolyrics.com/tillsonburg-lyrics -stompin-tom-connors.html (accessed 2019 Jan. 31).

2. Lillian Goldman Law Library, Yale Law School. I have a dream, by Martin Luther King Jr.; August 28 1963. Available: http://avalon.law.yale.edu/20th century/mlk01.asp (accessed 2019 Jan. 31).

3. AlSulais E, Roth LS, AlAmeel T. The prevalence of irritable bowel syndrome among board-certified medical doctors: a cross-sectional study. Am J Gastroenterology 2018;S268:Abstract 461.

This article has been peer reviewed. 